\title{
AGGLUTINATED BENTHIC FORAMINIFERA OF OCEAN DRILLING PROGRAM SITES 909 AND 913: IMPLICATIONS FOR EOCENE TO MIOCENE PALEOCEANOGRAPHY OF NORTHERN NORTH ATLANTIC
}

OSTERMAN, Lisa E., Department of Paleobiology, NHB-121, Smithsonian Institution, Washington, D.C., 20560, U.S.A.; SPIEGLER, Dorothee, GeomarResearch Center for Marine Geosciences, Wischhofstrassa 1-3, Building 4, D-24148 Kiel, F.R. Germany.

Deep-sea agglutinated foraminifera have been found in widely scattered Paleogene localities within the North Atlantic, including the Labrador, North and Norwegian Seas, and have proved to be a valuable tool in high latitude biostratigraphy. Recently, agglutinated benthic foraminifera have been identified in Eocene to Miocene sediments at Ocean Drilling Program (ODP) Sites 909 and 913 in the northern North Atlantic Ocean. Site $909\left(78^{\circ} 35.096^{\prime} \mathrm{N}, 3^{\circ} 4.222^{\prime} \mathrm{E}\right)$ is located at 2518 meters water depth (mwd) in the Fram Strait, and Site $913\left(75^{\circ} 29.365^{\prime} \mathrm{N}\right.$, $6^{\circ} 56.810^{\prime} \mathrm{W}$ ) is located at $3318.6 \mathrm{mwd}$ in the Greenland Basin on crust of magnetic anomaly $24 \mathrm{~B}$. These sites were chosen to study the timing of plate tectonic events that led to the opening of the Fram Strait and the initiation of deep water exchange between the Arctic and Atlantic Oceans.

At Site 909 (Fram Strait), four assemblages dominated by Reticulophragmium ex gr. rotundidorsata and Reticulophragmium amplectens range in age from middle to late Miocene. At Site 913 (Greenland Basin), five assemblages containing Reticulophragmium amplectens and Reophax abyssorum range from the early Eocene to Miocene. The stratigraphic ranges of the agglutinated benthic foraminifera of Site 913 (Greenland Basin) agree with previously published species ranges. However, the ranges of many of the agglutinated species at Site 909 (Fram Strait) extend into the upper Miocene. These are the youngest reported ranges for some agglutinated species in the North Atlantic basins.

These newly reported occurrences provide information about the deep-water exchange between the North Atlantic and the Arctic Ocean during the Eocene and Miocene. This study suggests that during the Miocene the Fram Strait was a high sedimentation, depositional basin with isolated bottom water. This depositional environment favored the preservation of the agglutinated benthic foraminiferal assemblages long after their disappearance from the rest of the North Atlantic. Deep water exchange did not occur between the North Atlantic and the Arctic Ocean during the Miocene in the Fram Strait area. 